\title{
Thermophysical and rheological properties of dulce de leche with and without coconut flakes as a function of temperature
}

\author{
Propriedades termofísicas e reológicas de doces de leite puro e adicionado de flocos de coco \\ em função da temperatura
}

\begin{abstract}
Vanessa Camarinha BARBOSA ${ }^{1}$, Edwin Elard GARCIA-ROJAS ${ }^{1,2}$, Jane Sélia dos Reis COIMBRA ${ }^{3}$, Paula de Aguiar CIPRIANO ${ }^{3}$, Eduardo Basílio de OLIVEIRA ${ }^{3}$, Javier TELIS-ROMERO ${ }^{4 *}$
\end{abstract}

\begin{abstract}
Dulce de leche (DL), a dairy dessert highly appreciated in Brazil, is a concentrated product containing about $70 \% \mathrm{~m} / \mathrm{m}$ of total solids. Thermophysical and rheological properties of two industrial Brazilian Dulce de leche formulations (classic Dulce de leche and Dulce de leche added with coconut flakes $1.5 \% \mathrm{~m} / \mathrm{m}$ ) were determined at temperatures comprised between 28.4 and $76.4^{\circ} \mathrm{C}$. In general, no significant differences $(\mathrm{p}<0.05)$ were observed in the presence of coconut flakes in the two formulations. Heat capacity varied from 2633.2 to $3101.8 \mathrm{~J} / \mathrm{kg}$. ${ }^{\circ} \mathrm{C}$; thermal conductivity from 0.383 to $0.452 \mathrm{~W} / \mathrm{m}$. ${ }^{\circ} \mathrm{C}$; specific mass from 1350.7 to $1310.7 \mathrm{~kg} / \mathrm{m}^{3}$; and, thermal diffusivity from $\left(1.082 \times 10^{-7}\right.$ to $\left.1.130 \times 10^{-7}\right) \mathrm{m}^{2} / \mathrm{s}$. The Bingham model was used to properly describe the non-Newtonian behavior of both formulations, with yielding stress values varying from 27.3 to $17.6 \mathrm{~Pa}$ and plastic viscosity from 19.9 to 5.9 Pa.s.

Keywords: Bingham model; dulce de leche; heat capacity; thermal conductivity; specific mass; thermal diffusivity.
\end{abstract}

\section{Resumo}

Doce de leite é uma sobremesa láctea concentrada (cerca de 70\% de sólidos) muito apreciada no Brasil. Propriedades termofísicas e reológicas de duas formulações de doce de leite brasileiro (puro e adicionado de coco ralado a 1,5\% em massa) foram determinadas a temperaturas compreendidas entre $28,4 \mathrm{e} 76,4^{\circ} \mathrm{C}$. No geral, a presença de flocos de coco não acarretou diferenças significativas $(\mathrm{p}<0,05)$ nestas propriedades das duas formulações. A capacidade calorífica variou entre $(2633,2$ e 3101,8$) \mathrm{J} / \mathrm{kg}$. ${ }^{\circ} \mathrm{C}$; a condutividade térmica entre $(0,383$ e 0,452$) \mathrm{W} / \mathrm{m}^{\circ} \mathrm{C}$; a massa específica entre $(1350,7$ e 1310,7$) \mathrm{kg} / \mathrm{m}^{3}$; e enfim, a difusividade térmica entre $\left(1,082 \times 10^{-7}\right.$ e 1,130 $\left.\times 10^{-7}\right) \mathrm{m}^{2} / \mathrm{s}$. O modelo de Bingham descreveu adequadamente o comportamento não Newtoniano dos dois produtos, com tensão crítica de escoamento variando entre (27,3 e 17,6) Pa e a viscosidade plástica de $(19,9$ a 5,9) Pa.s.

Palavras-chave: modelo de Bingham; doce de leite; capacidade calorifica; condutividade térmica; densidade; difusividade térmica.

\section{Introduction}

Dulce de leche is a kind of milk jam obtained by concentrating the mixture of milk and sucrose (approximately 20 mass \% of the total milk volume) under heat and normal or reduced pressure until nearly 70 mass $\%$ of total solids is reached (TAMIME, 2009). From a physicochemical point of view, it is a mixed aqueous dispersion composed mainly of carbohydrates (sucrose and lactose) and milk proteins, in which the continuous phase contains different types of dispersed particles. The typical mass composition of this product is: $30 \%$ of water (maximum); $6 \%$ of proteins (minimum); $2 \%$ of lipids (minimum); $2 \%$ of ashes (minimum); and $70 \%$ of sugars (maximum), of which $30 \%$ of sucrose (maximum) and the remaining corresponds to the milk lactose. Glucose and fructose syrup, sorbitol, corn starch, maltodextrin, chocolate, fruits puree, coconut powder, sodium bicarbonate, run, coffee, and vanilla extracts are also ingredients that can be used to create variations of the "traditional" dulce de leche (RANALLI; ANDRÉS; CALIFANO, 2011; TOLSTOGUZOV, 2000; NAVARRO; FERRERO; ZARITZKY, 1999; PAULETTI et al., 1990; HOUGH et al., 1988). The higher the solids content, the more consistent is the dulce.

The modern food industry requires products that are simultaneously low cost, safe, and attractive from both nutritional and sensorial point of view, thus needing constant technological upgrades. Accordingly, the knowledge of physical properties is essential for the design and periodic improvement in the machinery used in the food product processing, especially that involved in unit operations such as pumping and evaporation. Accurate thermophysical data of products (e.g., thermal conductivity, thermal diffusivity, heat capacity, and specific mass) are necessary, as well as determining their variation as a function of temperature during the processes. Also, the knowledge of rheological properties of processed

\section{Received 3/4/2012}

Accepted 31/10/2012 (005654)

${ }^{1}$ Universidade Federal Rural do Rio de Janeiro - UFRRJ, Rod. BR 465, Km 7, CEP 23890-000, Seropédica, RJ, Brasil

2 Departamento de Engenharia do Agronegocio, Universidade Federal Fluminense - UFF, CEP 27255-125, Volta Redonda, RJ, Brasil

${ }^{3}$ Departamento de Tecnologia de Alimentos, Universidade Federal de Viçosa - UFV, CEP 36571-000, Viçosa, MG, Brasil

${ }^{4}$ Departamento de Engenharia e Tecnologia de Alimentos, Universidade Estadual Paulista "Júlio de Mesquita Filho" - UNESP, CEP 15054-000, São José do Rio Preto, SP, Brasil,e-mail: javier@ibilce.unesp.br

${ }^{*}$ Corresponding author 
products is required because these properties are very useful in quality control, design of flow processes, and definition of transport and storage conditions. The flow characteristics determine the texture of products, which affects the perception and, thus, the acceptance by consumers. Rheological variables such as yielding stress, consistency index, and apparent viscosity are affected by the composition and the processing conditions of food products (GABAS et al., 2012; ASTOLFI-FILHO et al., 2012, 2011; MILANI; KOOCHEKI, 2011; REZAEI et al., 2011; CABRAL et al., 2007; GARITTA; HOUGH; SÁNCHEZ, 2004). In a few words, thermophysical and rheological data, and how they behave with temperature variations, are essential to a proper processing of the dulce de leche (DL) in order to avoid losses and to assure a good final quality.

Some studies dealing with the determination of physical properties of formulations of DL can be found in the literature. In such studies, the analyzed DL products had rheological behavior intermediate rheological behavior between that of the concentrated solution and that of the gel. Such differences are often attributed to the differences in the composition and type of ingredients used in the products' formulation. For instance, in some studies, DL sucrose was partially replaced by glucose syrup and sodium bicarbonate in order to avoid crystallization and protein coagulation; in others, coffee and vanilla extract were sometimes used for flavoring; and, in other cases, polyols and/ or hydrocolloids were used to improve the texture (RANALLI; ANDRÉS; CALIFANO, 2011; ZIMMERMANN et al., 2007; CORRADINI; PELEG, 2000; NAVARRO; FERRERO; ZARITZKY, 1999; HEIMLICH; BÓRQUEZ; CÉSPEDES, 1994; ROVEDO; VIOLLAZ; SUAREZ, 1991; PAULETTI et al., 1990). Even though these studies reported physical characterization of some DL formulations, to the best of our knowledge, specific studies dealing with the characterization of thermophysical and rheological properties of DL containing coconut flakes, which is very common in Brazil, are not yet available in the literature.

Therefore, the aim of the present study was to evaluate the thermophysical properties and the rheological behavior of typically Brazilian DL formulations, with and without coconut flakes. These properties were evaluated at temperatures ranging from 28.4 to $76.4{ }^{\circ} \mathrm{C}$, comprising the temperatures reached during preparation and storage.

\section{Materials and methods}

\subsection{Materials}

The Brazilian dulce de leche used for the measurements were manufactured by FUNARBE S.A. (Viçosa, MG, Brazil) and acquired from a commercial supermarket. Both products are commercialized as a food paste in $800 \mathrm{~g}$ packages. The DL without coconut flakes has the following mass composition: water $\approx 17.5 \%$, total sugars $\approx 65 \%$, proteins $\approx 10 \%$, and lipids $\approx 7.5 \%$. The composition of the DL with coconut flakes is: water $\approx 17 \%$, total sugars $\approx 64 \%$, proteins $\approx 10 \%$; lipids $\approx 7.5 \%$, and coconut flakes (mean diameter $\leq 1 \mathrm{~mm}$ ) $\approx 1.5 \%$. Both formulations contain traces of $\mathrm{Na}(\approx 100 \mathrm{mg} / 100 \mathrm{~g})$.

\subsection{Determination of thermophysical properties}

The thermophysical properties measurements (thermal conductivity, thermal diffusivity and specific mass) were performed in triplicate at each temperature $[(28.4,37.8,48.2$, $59.2,68.8$ and 76.4$)^{\circ} \mathrm{C}$ ] by taking samples from the top, center, and bottom of a same can. Prior to each experiment, the sample was kept at the working temperature using a thermostatic bath water (Marconi, MA-184, Brazil).

Thermal conductivity was measured according to the method described by Bellet, Sengelin and Thirriot (1975). This technique uses a cylindrical cell, composed of two coaxial cylinders with an annular space, which is filled with the liquid whose properties are to be determined. In order to keep the temperature constant, the cell was immersed in a thermostatic bath (Marconi, MA-184, Brazil) with an accuracy of $\pm 0.05^{\circ} \mathrm{C}$. The power input to the heater resistance inserted inside the inner cylinder was controlled using a microprocessor stabilizer source (Entelbra, ETB-252, Brazil), which allowed the adjustment of the electrical current with a stability of $0.05 \%$. The temperature was monitored using a data logger (HP, 75.000-B, USA) with an accuracy of $0.6^{\circ} \mathrm{C}$. The calibration of the cell was performed with distilled water and glycerin, according to Telis-Romero et al. (1998).

Thermal diffusivity was determined using the method proposed by Dickerson (1965). The experimental apparatus consisted of a cylindrical cell (internal radius $=0.025 \mathrm{~m}$ and length $=0.25 \mathrm{~m}$ ) made of chromium plated brass with two nylon covers with thermal diffusivity of $1.09 \times 10^{-7} \mathrm{~m}^{2} / \mathrm{s}$ in order to prevent axial heat diffusion. A type $\mathrm{T}$ thermocouple was fixed along the central axis of the cylinder and another one tangential to the external surface of the cylinder. The system (cylinder filled with dulce de leche + thermocouples) was immersed in a thermostatic bath (MLW, MK70, Germany) and heated at a constant rate. Temperatures were controlled using the same data acquisition system used in the thermal conductivity measurements. The changes in temperature were monitored both at the cell wall and the center of the cell.

Heat capacity was calculated from the thermal diffusivity definition using its formal definition:

$C p=\frac{\lambda}{\rho \alpha}$

where $C p$ is the heat capacity, $\lambda$ is the thermal conductivity, $\rho$ is the specific mass, and $\alpha$ is the thermal diffusivity.

Specific mass (density) was evaluated by the gravimetric method using an analytical balance (Mettler, AB204, USA; uncertainty of $\pm 0.0001 \mathrm{~g}$ ) and a standard volumetric pycnometer. The pycnometer of $25 \mathrm{~mL}$ was previously calibrated with distilled water at each temperature.

\subsection{Rheological measurements}

Rheological measurements were carried out using an AR2000 rheometer (TA Instruments, USA) with a cone and plate geometry (disk radius $=0.06 \mathrm{~m}$; angle $=4^{\circ}$ ) under controlled shear stress and temperature. Shear rate varied 
between ( 25 and 300) 1/s, and both upward and downward tests were performed in duplicate in the temperature range of (28.4 and 76.4) ${ }^{\circ} \mathrm{C}$. The experiments were performed as described in details by Astolfi-Filho et al. (2011).

\subsection{Data analysis}

All the regression model adjustments and statistical analyses (analyses of variance and Duncan test for comparison of means) were carried out using the SAS ${ }^{\bullet}$ software package (STATISTICAL..., 2009) licensed for the Federal University of Viçosa (Viçosa, MG, Brazil).

As for the thermophysical properties, $3^{\text {th }}$ order polynomial models (Equation 2) were adjusted to the obtained data.

$\psi=\beta_{0}+\beta_{1} \cdot T+\beta_{2} \cdot T^{2}+\beta_{3} \cdot T^{3}$

where $\psi$ is the thermophysical property, $\mathrm{T}$ is the temperature, and $\beta_{0}, \beta_{1}, \beta_{2}, \beta_{3}$ are the adjusted coefficients of Equation 2.

With regard to the rheological behavior, after examining the rheograms, the Bingham model (Equation 3) was adjusted to the experimental data for both DL formulations.

$$
\tau=\tau_{0}+\eta_{B} \cdot \dot{\gamma}
$$

This model was chosen because the analyzed fluids have yield stress $\left(\tau_{0}\right)>0$ and linear variations of the shear stress $(\tau)$ as a function of shear rate $(\dot{\gamma})$.

\section{Results and discussion}

Experimental data of heat capacity $\left(\mathrm{C}_{\mathrm{p}}\right)$, thermal conductivity $(\lambda)$, specific mass $(\rho)$, and thermal diffusivity $(\alpha)$ of the dulce de leche (DL) with and without the addition of coconut, at (28.4, $37.8,48.2,59.2,68.8$, and 76.4$)^{\circ} \mathrm{C}$, are shown in Table 1 . The variations in the values of these properties showed different trends with the increasing temperature. Heat capacity increased from 2633.2 to $3101.8 \mathrm{~J} / \mathrm{kg} .{ }^{\circ} \mathrm{C}$; thermal conductivity increased from 0.383 to $0.452 \mathrm{~W} / \mathrm{m}^{\circ} \mathrm{C}$; and thermal diffusivity increased from $1.082 \times 10^{-7}$ to $1.130 \times 10^{-7} \mathrm{~m}^{2} / \mathrm{s}$. Conversely, the specific mass values decreased with the temperature, varying from 1350.7 to $1310.7 \mathrm{~kg} / \mathrm{m}^{3}$. The same trend has been observed in the literature for other similar food products (MURAMATSU et al., 2010; TANSAKUL; CHAISAWANY, 2006). No statistically significant differences $(p<0.05)$ were found between the values determined for the formulations with and without coconut flakes, except for the specific mass at $59.2^{\circ} \mathrm{C}$, However, it is important to note that, in this case, the standard deviations values were higher than those observed for specific mass at other temperatures. This suggests that such difference may be simply due to variations in experiments.

With regard to the rheological behavior between 25 and 300 $1 / \mathrm{s}$, and yielding stress $\neq 0$, a linear relationship between shear stress $(\tau)$ and shear rate $(\dot{\gamma})$ was found at each temperature. The Bingham mathematical model (Equation 3) was appropriate to describe the behavior of both DL formulations in all cases $\left(\mathrm{R}^{2}\right.$ $\geq 0.98)$. The values of yield stress $\left(\tau_{0}\right)$ and plastic viscosity $\left(\eta_{B}\right)$ are shown in Table 2. As can be seen, an increase in temperature

Table 1. Thermophysical properties of dulce de leche with and without coconut flakes.

\begin{tabular}{|c|c|c|c|c|c|c|c|c|}
\hline \multirow[b]{2}{*}{$\begin{array}{c}\mathrm{T} \\
\left({ }^{\circ} \mathrm{C}\right)\end{array}$} & \multicolumn{2}{|c|}{$\mathrm{Cp}\left(\mathrm{J} / \mathrm{kg} \cdot{ }^{\circ} \mathrm{C}\right)$} & \multicolumn{2}{|c|}{$\lambda\left(\mathrm{W} / \mathrm{m} .{ }^{\circ} \mathrm{C}\right)$} & \multicolumn{2}{|c|}{$\rho\left(\mathrm{kg} / \mathrm{m}^{3}\right)$} & \multicolumn{2}{|c|}{$\alpha \cdot 10^{7}\left(\mathrm{~m}^{2} / \mathrm{s}\right)$} \\
\hline & $\begin{array}{c}\text { Without } \\
\text { conconut flakes }\end{array}$ & $\begin{array}{c}\text { With } \\
\text { coconut flakes }\end{array}$ & $\begin{array}{c}\text { Without } \\
\text { conconut flakes }\end{array}$ & $\begin{array}{c}\text { With } \\
\text { coconut flakes }\end{array}$ & $\begin{array}{c}\text { Without } \\
\text { conconut flakes }\end{array}$ & $\begin{array}{c}\text { With } \\
\text { coconut flakes }\end{array}$ & $\begin{array}{c}\text { Without } \\
\text { conconut flakes }\end{array}$ & $\begin{array}{c}\text { With } \\
\text { coconut flakes }\end{array}$ \\
\hline 28.4 & $2633.2 \pm 77.9^{a}$ & $2700.7 \pm 77.6^{a}$ & $0.383 \pm 0.010^{\mathrm{a}}$ & $0.395 \pm 0.013^{\mathrm{a}}$ & $1344.1 \pm 8.8^{\mathrm{a}}$ & $1350.7 \pm 11.9^{\mathrm{a}}$ & $1.083 \pm 0.003^{\mathrm{a}}$ & $1.082 \pm 0.006^{\mathrm{a}}$ \\
\hline 48.2 & $2835.2 \pm 2.4^{\mathrm{a}}$ & $2906.8 \pm 80.0^{\mathrm{a}}$ & $0.406 \pm 0.011^{\mathrm{a}}$ & $0.418 \pm 0.015^{\mathrm{a}}$ & $1325.7 \pm 9.0^{\mathrm{a}}$ & $1332.2 \pm 16.2^{\mathrm{a}}$ & $1.080 \pm 0.021^{\mathrm{a}}$ & $1.079 \pm 0.018^{\mathrm{a}}$ \\
\hline 59.2 & $2795.8 \pm 115.6^{\mathrm{a}}$ & $2871.4 \pm 81.8^{\mathrm{a}}$ & $0.418 \pm 0.012^{\mathrm{a}}$ & $0.431 \pm 0.012^{\mathrm{a}}$ & $1325.8 \pm 17.3^{\mathrm{a}}$ & $1332.4 \pm 19.3^{b}$ & $1.129 \pm 0.010^{\mathrm{a}}$ & $1.128 \pm 0.013^{\mathrm{a}}$ \\
\hline
\end{tabular}

Cp: heat capacity; $\lambda$ : thermal conductivity; $\rho$ : specific mass; $\alpha$ : thermal diffusity. For each property, at each temperature, the values which are not statistically different $(p<0.05)$ are accompanied by the same letter $(a)$, and values which are statistically different $(\mathrm{p}<0.05)$ are accompanied by different letters $(\mathrm{a}$ and $\mathrm{b})$.

Table 2. Coefficients of the $3^{\text {rd }}$ order polynomial model adjusted to thermophysical properties as a function of temperature $\left(28.4^{\circ} \mathrm{C}\right.$ T $\left.\leq 76.4^{\circ} \mathrm{C}\right)$.

\begin{tabular}{|c|c|c|c|c|c|c|}
\hline \multirow{2}{*}{$\begin{array}{c}\text { Property } \\
(\psi)\end{array}$} & \multirow{2}{*}{$\begin{array}{c}\text { Formulation } \\
\text { of dulce de leche }\end{array}$} & \multicolumn{5}{|c|}{ Coefficients of $\psi=\beta_{0}+\beta_{1} \cdot T+\beta_{2} \cdot T^{2}+\beta_{3} \cdot T^{3 *}$} \\
\hline & & $\beta_{0}$ & $\beta_{1}$ & $\beta_{2}$ & $\beta_{3}$ & $R^{2}$ \\
\hline $\begin{array}{c}C p \\
\left(\mathrm{~J} / \mathrm{kg} \cdot{ }^{\circ} \mathrm{C}\right)\end{array}$ & Without coconut & 1367.566 & 78.628 & -1.495 & 0.009 & 0.94 \\
\hline \multirow{2}{*}{$\begin{array}{c}\lambda \\
\left(\mathrm{W} / \mathrm{m} .{ }^{\circ} \mathrm{C}\right)\end{array}$} & Without coconut & 0.365 & $1.32 \times 10^{-4}$ & $2.06 \times 10^{-5}$ & $-1.273 \times 10^{-7}$ & 0.99 \\
\hline & With coconut & 0.384 & $-3.21 \times 10^{-4}$ & $3.02 \times 10^{-5}$ & $-1.877 \times 10^{-7}$ & 0.99 \\
\hline $\begin{array}{c}\rho \\
\left(\mathrm{kg} / \mathrm{m}^{3}\right)\end{array}$ & Without coconut & 1492.178 & -9.211 & 0.174 & -0.001 & 0.85 \\
\hline $\begin{array}{c}a \\
\left(\mathrm{~m}^{2} / \mathrm{s}\right)\end{array}$ & With coconut & $1.412 \times 10^{-7}$ & $-2.31 \times 10^{-9}$ & $5.028 \times 10^{-11}$ & $-3.309 \times 10^{-13}$ & 0.73 \\
\hline \multirow{2}{*}{$\begin{array}{c}\eta_{\mathrm{B}} \\
(\mathrm{Pa} . \mathrm{s})\end{array}$} & Without coconut & 41.570 & -1.111 & 0.013 & $-6.259 \times 10^{-5}$ & 0.99 \\
\hline & With coconut & 46.916 & -1.420 & 0.019 & $-1.059 \times 10^{-4}$ & 0.99 \\
\hline
\end{tabular}

${ }^{*}$ Statistically significant $(\mathrm{p}<0.05)$ coefficients. 
led to a decrease of both parameters: the yield stress decreased from 27.3 to $17.6 \mathrm{~Pa}$ and plastic viscosity $\left(\eta_{\mathrm{B}}\right)$ from 19.9 to $5.9 \mathrm{~Pa} \cdot \mathrm{s}$. These results mean that the product becomes less viscous (more fluid) as its temperature rises (RAO, 1999). A similar rheological behavior was previously reported by Rovedo, Viollaz and Suarez (1991) for Argentinian dulce de leche market samples. No significant difference $(\mathrm{p}<0.05)$ was observed in the rheological parameters of the DLs studied, except for the

Table 3. Rheological parameters of the Bingham model for dulce de leche with and without coconut flakes.

\begin{tabular}{cccccc}
\hline $\mathrm{T}$ & \multicolumn{3}{c}{$\tau_{0}(\mathrm{~Pa})$} & & \multicolumn{2}{c}{$\eta_{\mathrm{B}}($ Pa.s $)$} \\
\cline { 2 - 3 } \cline { 5 - 6 }$\left({ }^{\circ} \mathrm{C}\right)$ & Without coconut flakes & With conconut flakes & & Without coconut flakes & With conconut flakes \\
\hline 28.4 & $24.873 \pm 1.232^{\mathrm{a}}$ & $27.359 \pm 1.094^{\mathrm{a}}$ & & $19.171 \pm 0.482^{\mathrm{a}}$ & $19.963 \pm 0.826^{\mathrm{a}}$ \\
37.8 & $23.853 \pm 1.182^{\mathrm{a}}$ & $26.238 \pm 1.049^{\mathrm{a}}$ & & $15.329 \pm 0.385^{\mathrm{a}}$ & $15.961 \pm 0.660^{\mathrm{a}}$ \\
48.2 & $22.786 \pm 1.976^{\mathrm{a}}$ & $24.738 \pm 1.520^{\mathrm{b}}$ & & $11.651 \pm 0.355^{\mathrm{a}}$ & $12.135 \pm 1.021^{\mathrm{a}}$ \\
59.2 & $21.530 \pm 1.603^{\mathrm{a}}$ & $21.962 \pm 1.755^{\mathrm{a}}$ & & $8.999 \pm 0.452^{\mathrm{a}}$ & $9.975 \pm 1.191^{\mathrm{a}}$ \\
68.8 & $19.480 \pm 0.965^{\mathrm{a}}$ & $21.998 \pm 0.502^{\mathrm{a}}$ & & $7.782 \pm 0.118^{\mathrm{a}}$ & $8.220 \pm 0.541^{\mathrm{a}}$ \\
76.4 & $17.630 \pm 1.529^{\mathrm{a}}$ & $19.140 \pm 1.176^{\mathrm{b}}$ & & $5.954 \pm 0.181^{\mathrm{a}}$ & $6.203 \pm 0.522^{\mathrm{a}}$ \\
\hline
\end{tabular}

$\tau_{0}$ : Initial shear stress; $\eta_{\mathrm{B}}$ : plastic viscosity of Bingham. For each parameter, at each temperature, the values which are not statistically different $(p<0.05)$ are accompanied by the same letter $(\mathrm{a})$, and the values which are statistically different $(\mathrm{p}<0.05)$ are accompanied by different letters $(\mathrm{a}$ and $\mathrm{b})$.
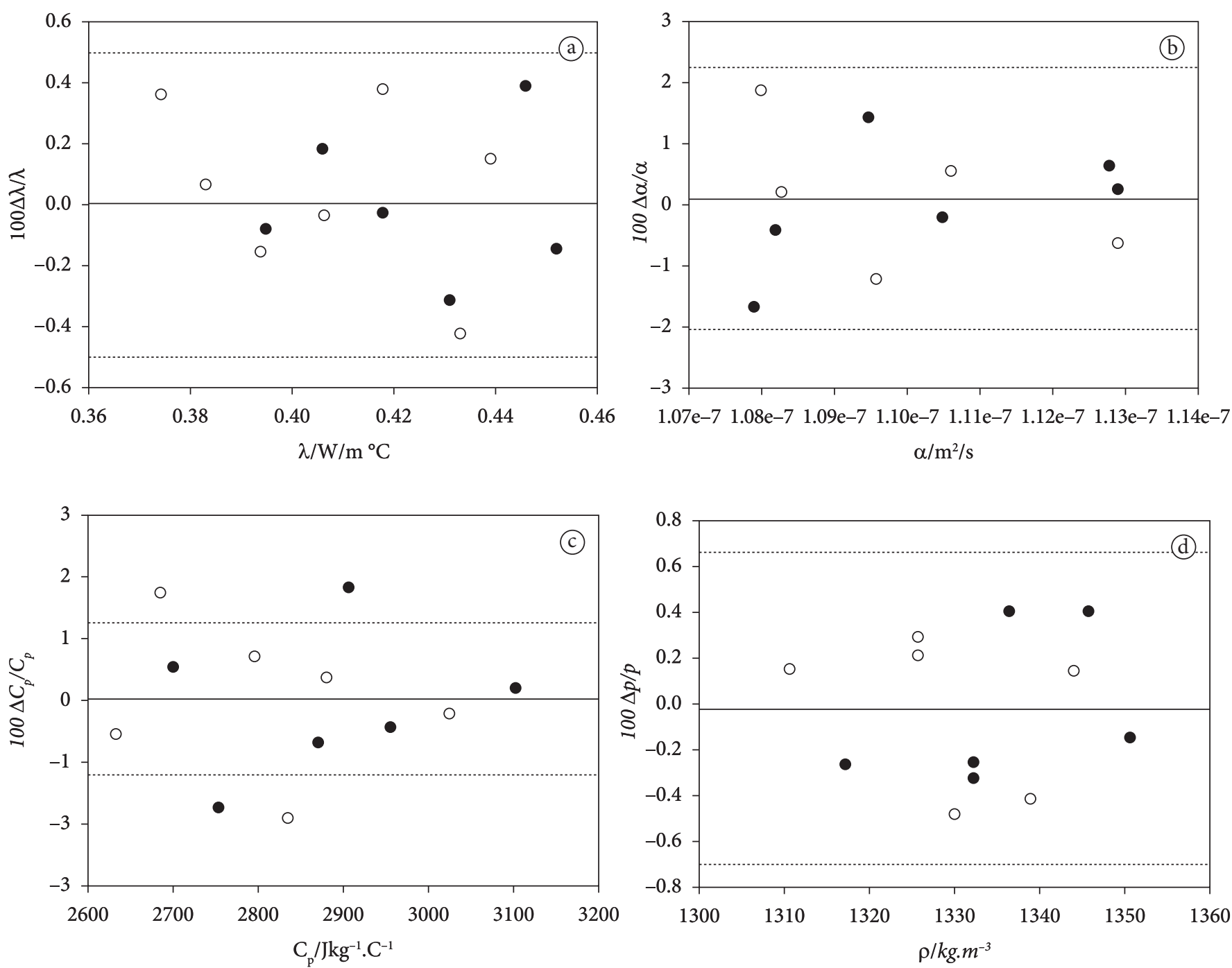

Figure 1. Fractional deviations between the thermophysical properties and the corresponding relative errors (standard deviation adjustment using Equation 2, between $\pm 2 \sigma$ ). (a) Thermal conductivity, (b) thermal diffusivity, (c) heat capacity, and (d) specific mass. Legend: $\circ$ DL without coconut flakes and $\bullet$ DL with coconut flakes. 


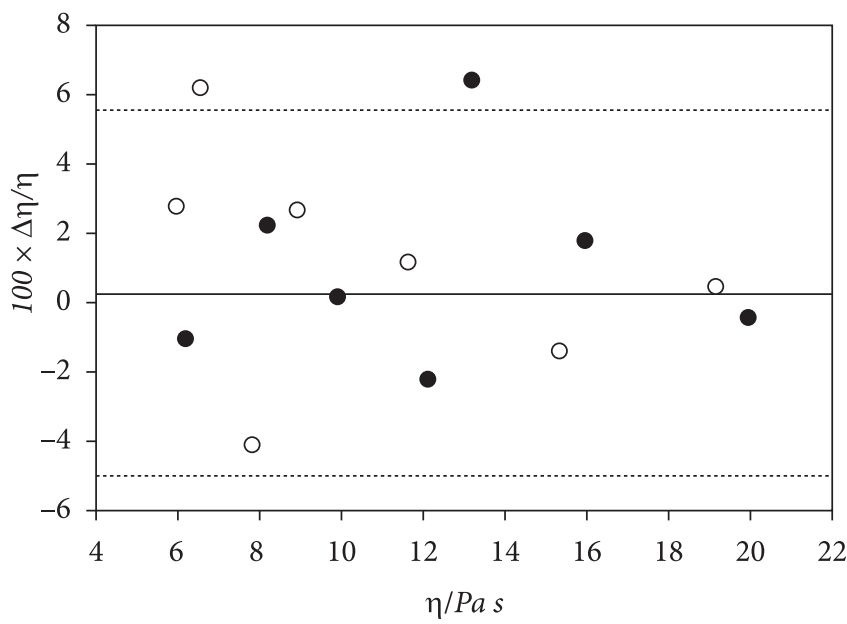

Figure 2. Fractional deviations between the experimental plastic viscosity and the corresponding relative error (standard deviation adjustment using Equation 2, between $\pm 2 \sigma$ ). Legend: $\circ \mathrm{DL}$ without coconut flakes and $\bullet$ DL with coconut flakes.

yield stress at $48.2^{\circ} \mathrm{C}$ and $76^{\circ} \mathrm{C}$. Nevertheless, as suggested by the values of standard deviations, such difference is again likely to be due to experimental variations.

A polynomial mathematical model of the third order (Equation 2) was fitted to experimental data for thermophysical and rheological properties as a function $(\psi)$ of the temperature. The found regression coefficients of Equation 2 for $\mathrm{Cp}, \lambda$, $\rho, \alpha$, and $\eta_{B}$ are shown in Table 3. Figure 1 (thermophysical properties) and Figure 2 (rheological properties) present the fractional deviations between the experimentally obtained data and the relative errors for these parameters. These data, along with the determination coefficients $\left(R^{2} \geq 0.7\right.$ in all cases), indicate that the polynomial models can be considered satisfactory to mathematically represent these variations as a function of temperature within the considered interval (MONTGOMERY; RUNGER; HUBELE, 2004).

In general, the evaluation of thermophysical and rheological data for the dulce de leche with coconut flakes (amount added $=1.5 \% \mathrm{~m} / \mathrm{m})$ indicated no significant differences in the comparison of means $(\mathrm{p}<0.05)$ as compared with classic dulce de leche at the same temperature However, the physical properties values were affected by the temperature increase.

\section{Conclusions}

Thermophysical properties (thermal conductivity, thermal diffusivity, heat capacity, and specific mass) and the rheological behavior of Brazilian dulce de leche (DL) with and without coconut flakes were evaluated at temperatures comprised between 28.4 and $76.4{ }^{\circ} \mathrm{C}$. The Bingham model was proven adequate to mathematically represent the rheology of these two products at each different temperature considered. In general, statistically significant differences were not found when comparing these physical properties of the DL formulations with and without coconut flakes at a given temperature. Third order polynomial models were satisfactorily adjusted to the experimental data in order to represent the variations of $\mathrm{Cp}, \lambda$, $\rho, \alpha$, and $\eta_{B}$ as a function of temperature. All these findings can help guide the industrial processing of these two kinds of DL suggesting that no changes are needed in terms of machinery and process parameters when coconut flakes are included in the formulations up to $1.5 \% \mathrm{~m} / \mathrm{m}$.

\section{Acknowledgements}

The authors are grateful to CNPq, CAPES, FAPEMIG, FAPESP, FAPERJ, and FUNARBE for the financial support and grants.

\section{References}

ASTOLFI-FILHO, Z. et al. Rheology and fluid dynamics properties of industrial sugarcane juices. Biochemical Engineering Journal, v. 53, p. 260-265, 2011. http://dx.doi.org/10.1016/j.bej.2010.11.004

ASTOLFI-FILHO, Z. et al. Friction factors, convective heat transfer coefficients and the Colburn analogy for industrial sugarcane juices. Biochemical Engineering Journal, v. 60, p. 111-118, 2012. http:// dx.doi.org/10.1016/j.bej.2011.10.011

BELLET, D.; SENGELIN, M.; THIRRIOT, C. Thermophysical properties determination of non Newtonian liquids in a coaxial cylinder cell. International Journal of Heat and Mass Transfer, v. 18 , p. $1177-1187,1975$. http://dx.doi.org/10.1016/00179310(75)90139-8

CABRAL, R. A. F. et al. Rheological and thermophysical properties of blackberry juice. Ciência e Tecnologia de Alimentos, v. 27 , p. 589-596, 2007. http://dx.doi.org/10.1590/S010120612007000300025

CORRADINI, M. G.; PELEG, M. Lubricated squeezing flow viscometry for dulce de leche (milk sweet). Food Science and Technology International, v. 6, p. 339-344, 2000. http://dx.doi. org/10.1177/108201320000600409

DICKERSON, R. W. An apparatus for measurements of thermal diffusivity of foods. Food Technology, v. 19, p. 198-204, 1965.

GABAS, A. L. et al. Density and rheological parameters of goat milk. Ciência e Tecnologia de Alimentos, v. 32, p. 381-385, 2012.

GARITTA, L.; HOUGH, G.; SÁNCHEZ, R. Sensory shelf life of dulce de leche. Journal of Dairy Science, v. 87, p. 1601-1607, 2004. http:// dx.doi.org/10.3168/jds.S0022-0302(04)73314-7

HEIMLICH, W.; BÓRQUEZ, R.; CÉSPEDES, I. Effects of milk replacement by whey protein concentrates on the rheological properties of dulce de leche. LWT - Food Science and Technology, v. 27, p. 289-291, 1994.

HOUGH, G. et al. Flow properties of dulce de leche, a typical argentine dairy product. Journal of Dairy Science, v. 71, p. 1783-1788, 1988. http://dx.doi.org/10.3168/jds.S0022-0302(88)79746-5

MILANI, E.; KOOCHEKI, A. The effects of date syrup and guar gum on physical, rheological and sensory properties of low fat frozen yoghurt dessert. International Journal of Dairy Technology, v. 64, p. 121-129, 2011. http://dx.doi.org/10.1111/j.14710307.2010.00631.x

MONTGOMERY, D. C.; RUNGER, G. C.; HUBELE, N. F. Estatística Aplicada à Engenharia. 2. ed. Rio de Janeiro: LTC, 2004.

MURAMATSU, Y. et al. Simultaneous estimation of the thermophysical properties of three kinds of fruit juices based on the measured result by a transient heat flow probe method. Journal of Food 
Engineering, v. 96, p. 607-613, 2010. http://dx.doi.org/10.1016/j. jfoodeng.2009.09.008

NAVARRO, A. S.; FERRERO, C.; ZARITZKY, N. E. Rheological characterization of dulce de leche by dynamic and steady smear measurements. Journal of Texture Studies, v. 30, p. 43-58, 1999. http://dx.doi.org/10.1111/j.1745-4603.1999.tb00201.x

PAULETTI, M. et al. Rheological characterization of dulce de leche, a confectionery dairy product. Journal of Dairy Science, v. 73, p. 601-603, 1990. http://dx.doi.org/10.3168/jds.S00220302(90)78708-5

RANALLI, N.; ANDRÉS, S.; CALIFANO, A. Physicochemical and rheological characterization of "dulce de leche". Journal of Texture Studies, v. 43, p. 115-123, 2012. http://dx.doi.org/10.1111/j.17454603.2011.00321.x

RAO, M. A. Rheology of Fluid and Semifluid Foods: Principles and Applications. Gaithersburg: Aspen Publication, 1999.

REZAEI, R. et al. Effect of guar gum and arabic gum on the physicochemical, sensory and flow behaviour characteristics of frozen yoghurt. International Journal of Dairy Technology, v. 64, p. 563-568, 2011. http://dx.doi.org/10.1111/j.14710307.2011.00705.x

ROVEDO, C. O.; VIOLLAZ, P. E.; SUAREZ, C. The effect of $\mathrm{pH}$ and temperature on the rheological behavior of dulce de leche, a typical dairy Argentine product. Journal of Dairy Science, v. 74, p. 1497-1502, 1991. http://dx.doi.org/10.3168/jds.S00220302(91)78309-4

STATISTICAL ANALISYS SYSTEM INSTITUTE - SAS. SAS/STAT 9.2 User's Guide. 2nd ed. Cary: SAS Institute Inc. 2009.

TAMIME, A. Y. Dairy Powders and Concentrated Products. John Wiley \& Sons, 2009. http://dx.doi.org/10.1002/9781444322729

TANSAKUL, A.; CHAISAWANY, P. Thermophysical properties of coconut milk. Journal of Food Engineering, v. 73, p. 276-280, 2006. http://dx.doi.org/10.1016/j.jfoodeng.2005.01.035

TELIS-ROMERO, J. et al. Thermophysical properties of brazilian orange juice as affected by temperature and water content. Journal of Food Engineering, v. 38, p. 27-40, 1998. http://dx.doi. org/10.1016/S0260-8774(98)00107-1

TOLSTOGUZOV, V. Foods as dispersed systems. Thermodynamic aspects of composition-property relationships in formulated food. Journal of Thermal Analysis and Calorimetry, v. 61, p. 397-409, 2000. http://dx.doi.org/10.1023/A:1010109232049

ZIMMERMANN, J. V. et al. Physicochemical, sensorial and rheological properties of doce de leite with xanthan gum and whey protein concentrate. Publication of Universidade Estadual de Ponta Grossa (UEPG), v. 13, p. 53-59, 2007. 